\title{
Effects of Cimetidine on Various Biological Activities of Human Leucocyte Interferon and on Interferon Production in Lymphocytes
}

\author{
Nobuyuki Hirai, ${ }^{*}$ Nobu Hattori, ${ }^{*}$ Norwood O. Hill ${ }^{+}$ \\ and Kurt Osther ${ }^{+}$ \\ *The First Department of Internal Medicine, School of \\ Medicine, Kanazawa University, Kanazawa 920, and \\ +Wadley Institutes of Molecular Medicine, 9000 Harry \\ Hines Blvd., Dallas, Texas 75235, USA
}

\begin{abstract}
Hirai, N., Hattori, N., Hill, N.O. and Osther, K. Effects of Cimetidine on Various Biological Activities of Human Leucocyte Interferon and on Interferon Production in Lymphocytes. Tohoku J. exp. Med., 1985, 147 (2), 199-212 — In vitro effects of cimetidine on the antiviral, the antiproliferative and the natural killer (NK) cell stimulating activities of human leucocyte interferon (IFN- $\alpha$ (Le)), and on the Sendai virus induced interferon production in lymphocytes were investigated. The antiviral activity of IFN- $\alpha$ (Le) was dosedependently enhanced by cimetidine, which alone did not demonstrate any antiviral action. The observed titer of the same IFN preparation titrated with $60 \mu \mathrm{g} / \mathrm{ml}$ of cimetidine was significantly higher $(p<0.05)$ than that without cimetidine. Cimetidine slightly but dosedependently inhibited the growth of Daudi or G-361 cells. The combination effects of these two agents were revealed to be statistically additive or synergistic. The NK cell activity of peripheral blood lymphocytes (PBL) was suppressed after a $16 \mathrm{hr}$ pretreatment with cimetidine. Furthermore, the interferon production in normal lymphocyte cultures was suppressed dosedependently by cimetidine. On the other hand, the augmentation of the NK cell activity by interferon was further potentiated by cimetidine. cimetidine; human leucocyte interferon; antiviral action; antiproliferative action ; NK augmenting action
\end{abstract}

Interferons (IFN) have various biological activities (Stwart II 1979). Based upon the in vitro and in vivo established antiproliferative activity or immunomodulatory effects of IFN, extensive clinical trials of IFN against various malignant tumors are now under investigation.

On the other hand, several recent reports have indicated that cimetidine may

Received May 8, 1985 ; accepted for publication August 7, 1985.

All correspondence should be addressed to the first author.

Part of the present study was orally presented at "The 43rd Annual Meeting of The Japanese Cancer Association" in October, 1984, at Fukuoka. 
have probable antitumoral effects (Armitage and Sindner 1979; Tutton and Steel 1979; Tutton and Barkla 1983; Gifford et al. 1981b; Osband et al. 1981). Furthermore, it has been also reported that the combination therapy of IFN- $\alpha$ (Le) and cimetidine in malignant melanoma patients produced more prominent responcss than did IFN- $\alpha$ (Le) alone (Borgeström et al. 1982 ; Hill et al. 1983) Thus, cimetidine seems to be beneficial in cancer treatments especially when combined with interferon therapy.

The purpose of the present study is to explore the effects of cimetidine on the interferon system. The effects of cimetidine on the antiviral activity, the antiproliferative activity and the NK augmenting effect of IFN- $\alpha$ (Le) were investigated in vitro. Furthermore, the influence of cimetidine on the Sendai virus induced interferon production in normal peripheral blood lymphocytes (PBL) has also been studied.

\section{Materials and Methods}

\section{Cell lines}

U cells, a human amnion cell line obtained from Dr. K. Cantell, were used for the study of the antiviral activity of IFN- $\alpha$ (Le). Daudi cells, a Burkitt lymphoma cell line, and G361 cells, a human malignant melanoma cell line, were used to evaluate the antiproliferative activity of IFN- $\alpha$ (Le). K-562 cells, a human myeloid cell line, PLC/PRF/5 cells, a human hepatoma cell line, and G-361 cells were used as the target cells in the assays of the NK cell activity.

\section{Viruses}

Vesicular stomatitis virus (VSV) was used as the challenge virus in the assay of the antiviral activity. Sendai virus was used as the inducer of the interferon production in PBL. Both viruses were kind gifts of Dr. K. Cantell.

\section{Interferon}

Human leucocyte interferon (HuIFN- $\alpha$ (Le)) was produced from donor buffy coats induced by Sendai virus and partially purified according to the methods described by Cantell et al. (1981). The titer was established by the plaque reduction assay on U cells challenged by VSV referring to the NIH standard interferon- $\alpha$ (Lot No. G023-901-527). The specific activity of IFN- $\alpha$ (Le) preparation used in this study was $1.3-3.5 \times 10^{6} \mathrm{IU} / \mathrm{mg}$ protein. The antigenic properties of the same kind of human leucocyte interferon (IFN- $\alpha$ (Le)) prefaration was previously evaluated by Berg et al. (1980), and revealed to contain $99 \%$ L-form (IFN- $\alpha$ ) and $1 \% \mathrm{~F}$-form $($ IFN- $\beta$ ).

\section{Cimetidine}

Cimetidine- $\mathrm{HCl}$ (Smith \& Kline Lab. Co.), $150 \mathrm{mg} / \mathrm{ml}$ solution for clinical use, was diluted in culture medium, $\mathrm{pH}$ was adjusted to $7.2-7.4$ and used.

Tests for the antiviral activity

A macroplaque reduction assay on U cells challenged by VSV was performed as previously described (Langford et al. 1981). Briefly, $1.2 \times 10^{6}$ of $\mathrm{U}$ cells which had grown in a $6 \mathrm{~cm}$ culture dish were incubated with various concentrations of IFN and cimetidine. After an overnight incubation, the cells were washed and challenged by $100-150$ PFU of VSV for $1 \mathrm{hr}$. Then, the monolayer was covered with an ager gel and the viral plaque 
developed. After staining, the plaques were counted and the reciprocal of the IFN dilution that gives $50 \%$ reduction of viral plaque number was calculated as the observed titer.

\section{Tests for the antiproliferative activity}

$6 \times 10^{5}$ of Daudi cells were cultured with various concentrations of IFN and cimetidine for 3 days and viable cell number was counted in a hemacytemeter chamber using $2.5 \%$ Trypan Blue solution (GIBCO). G-361 cells, $2 \times 10^{4} /$ well, were cultured in a 24 -well culture plate with various concentrations of IFN and cimetidine for 4 days. The medium was refreshed in every $24 \mathrm{hr}$. Then, they were trypsinized and counted as was done in the Daudi cell experiments. The percentage of cell growth inhibition (relative cell number reduction to control) was calculated.

\section{Tests for the NK cell activity}

In each experiment, PBL were preparated from a normal donor blood as previously described (Yamauchi et al. 1979). Then PBL were treated with various concentrations of IFN and cimetidine, in the same time or one by one, for several time lengths and used as the effector cells. The ${ }^{51} \mathrm{Cr}$ releasing cytotoxicity assay was performed as described before (Yamauchi et al. 1979). Briefly, the target cells labelled with $\mathrm{Na}_{2}{ }^{51} \mathrm{CrO}_{4}$ (ICN Chemical \& Radioisotope) were washed and seeded in 96 -well U plates at a concentration of $1.5 \times 10^{4}$ cells/well with Dulbecco's MEM (DMEM) $/ 5 \%$ fetal calf serum. In some experiments using G-361 or PLC/PRF/5 cells, which were monolayer cultures, they were washed after an overnight incubation. Then, the effector cells were added to each well in a concentration of $7.5 \times 10^{5}$ cells $/$ well $(\mathrm{E} / \mathrm{T}$ ratio $=50)$ and in a final volume of $200 \mu \mathrm{l} /$ well. The plates were centrifuged at $200 \mathrm{~g}$ for $10 \mathrm{~min}$. After a 4 or $16 \mathrm{hr}$ incubation, the plates were recentrifuged and the radioactivity of the $100 \mu \mathrm{l}$ supernatant from each well was counted by a gamma counter. The NK cell activity was calculated by the following formula:

$$
\mathrm{NK} \text { cell activity }=\frac{(\text { Experimental }- \text { Spontaneous }) \text { release }}{(\text { Maximum }- \text { Spontaneous }) \text { release }} \times 100,(\%)
$$

where spontaneous release is the count obtained when target cells were incubated without effector cells, and maximum release is that when they were incubated in the medium containing $2.5 \%$ saponin.

\section{Interferon production in $P B L$ cultures}

$5 \times 10^{6}$ cells/well of PBL were incubated with several concentrations of cimetidine at $37^{\circ} \mathrm{C}$ for $16 \mathrm{hr}$. After washed, $6 \times 10^{6}$ cells/well from each group were transferred in to a $24-$ well culture plate and primed with $100 \mathrm{IU} / \mathrm{ml}$ of IFN- $\alpha$ (Le) for $2 \mathrm{hr}$. Then, $150 \mathrm{HAU} / \mathrm{ml}$ of Sendai virus was added to each well and cultured in the final volume of $1.5 \mathrm{ml} /$ well for $24 \mathrm{hr}$ in a $37^{\circ} \mathrm{C} / 5 \% \mathrm{CO}_{2}$ atmosphere. The supernatant from each well was centrifuged at $800 \mathrm{~g}$ for $10 \mathrm{~min}$, UV-irradiated to inactivate the remaining virus, and kept at $-20^{\circ} \mathrm{C}$ until it was assayed. The IFN yield of each sample was assayed by the plaque reduction assay as mentioned above.

\section{Statistical analysis}

To compare the mean, Student's $t$-test was employed, and the differences with $p$ values below 0.05 were considered to be significant. The analysis of the combination effects of two agents was performed as following. In each combination, the expected value, the combination index (CI), and the combined standard error (SE) were calculated following the theory described by Spector et al. (1982). The combination effect was considered to be synergistic when $\mathrm{CI} / \mathrm{SE}$ was more than +2.0 , to be additive when $\mathrm{CI} / \mathrm{SE}$ was between -2.0 and +2.0 , and to be antagonistic when $\mathrm{CI} / \mathrm{SE}$ was less than -2.0 . 
TABLE 1. Influence of cimetidine on the antiviral activity of HuIFN- $\alpha$ (Le) in $U$ amnion cells challenged with VSV*

\section{Log titers of interferon}

Cimetidine concentration $(\mu \mathrm{g} / \mathrm{ml})$

\begin{tabular}{lcccc} 
& 0 (control) & 0.6 & 6 & 60 \\
\hline Exp. 1 & 5.90 & 6.10 & 6.64 & 6.67 \\
& $(0.980 \dagger)$ & $(0.997)$ & $(0.983)$ & $(0.987)$ \\
Exp. 2 & 5.72 & 6.07 & 6.24 & 6.26 \\
& $(0.999)$ & $(0.993)$ & $(0.997)$ & $(0.999)$ \\
Exp. 3 & 5.61 & 5.97 & 5.89 & 6.10 \\
& $(0.997)$ & $(0.999)$ & $(0.997)$ & $(0.997)$ \\
\hline Mean \pm S.D. & $5.75 \pm 0.15$ & $5.98 \pm 0.18$ & $6.26 \pm 0.38$ & $6.33 \pm 0.30 \ddagger$ \\
{$[$ U/ml $]$} & {$\left[5.6 \times 10^{5}\right]$} & {$\left[6.0 \times 10^{5}\right]$} & {$\left[1.8 \times 10^{6}\right]$} & {$\left[2.1 \times 10^{6}\right]$} \\
S.D. & 0.15 & 0.18 & 0.38 & 0.30 \\
\hline
\end{tabular}

* U amnion cells were incubated with interferon and cimetidine overnight, washed and challenged with VSV.

$\dagger$ The correlation coeffcient in each titration is given in the parenthesis.

$\ddagger$ The mean value of log titers is significantly different $(p<0.05)$ from that of control.

TABLE 2. Plaque reduction assay performed on $U$ amnion cells using interferon and cimetidine*

\begin{tabular}{lcccc}
\hline \multirow{2}{*}{$\begin{array}{c}\text { Dilution of } \\
\text { HuIFN- } \alpha \text { (Le) } \\
(\text { concentration })\end{array}$} & \multicolumn{4}{c}{$\begin{array}{c}\text { Plaque counts in interferon/cimetidine combination } \\
\text { Cimetidine concentration }(\mu \mathrm{g} / \mathrm{ml})\end{array}$} \\
\cline { 2 - 5 } & $0($ control $)$ & 0.6 & 6 & 60 \\
\hline $1: 1.2 \times 10^{5}$ & $38-42-42$ & $28-27-30$ & $23-18-25$ & $16-18-15$ \\
$(12.5 \mathrm{IU} / \mathrm{ml})$ & $(41)$ & $(28)$ & $(22)$ & $(16)$ \\
$1: 4.0 \times 10^{5}$ & $76-68-74$ & $46-45-54$ & $44-42-43$ & $40-45-47$ \\
$(3.8 \mathrm{IU} / \mathrm{ml})$ & $(73)$ & $(48)$ & $(42)$ & $(44)$ \\
$1: 1.2 \times 10^{6}$ & $98-102-102$ & $87-85-78$ & $71-75-74$ & $65-70-75$ \\
$(1.3 \mathrm{IU} / \mathrm{ml})$ & $(101)$ & $(83)$ & $(73)$ & $(70)$ \\
$1: 4.0 \times 10^{6}$ & $136-123-126$ & $107-108-105$ & $100-94-99$ & $92-100-96$ \\
$(0.4 \mathrm{IU} / \mathrm{ml})$ & $(128)$ & $(107)$ & $(98)$ & $(96)$ \\
virus control & $153-164-157$ & $159-160-156$ & $156-162-159$ & $158-155-160$ \\
$($ no IFN) & $(158)$ & $(158)$ & $(159)$ & $(158)$ \\
\hline Log titer & 5.72 & 6.07 & 6.24 & 6.26 \\
{$[\mathrm{U} / \mathrm{ml}]$} & {$\left[5.3 \times 10^{5}\right]$} & {$\left[1.2 \times 10^{6}\right]$} & {$\left[1.7 \times 10^{6}\right]$} & {$\left[1.8 \times 10^{6}\right]$} \\
$\mathrm{r}$ & 0.999 & 0.993 & 0.997 & 0.999 \\
\hline
\end{tabular}

* Actual plaque counts from experiment 2 in TABLE 1 are shown and the average plaque numbers are given in parenthesis.

$\dagger$ Human leucocyte interferon (HuIFN- $\alpha$ (Le)), specific activity ; $3.5 \times 10^{6} \mathrm{IU} / \mathrm{mg}$ protein, undiluted sample at $1.5 \times 10^{6} \mathrm{IU} / \mathrm{ml}$.

$r$, correlation coefficient. 


\section{Results}

Influence of cimetidine on the antiviral activity of $\operatorname{IFN}-\alpha(L e)$

Effects of cimetidine on the antiviral activity was explored by titrating the same IFN- $\alpha$ (Le) preparation in the presence of cimetidine on $\mathrm{U}$ amnion cells challenged by VSV. Table 1 summarizes the results of three titrations and in Table 2, the actual plaque counts in one of these titrations are shown. The observed titer of the same IFN preparation was inceased according to the increment of the cimetidine concentration in each titration (Table 1), whereas the plaque counts on the virus control dish (no interferon) was not affected by cimetidine (Table 2 ) indicating that cimetidine alone does not induce any antiviral state at all in the U cell cultures. The mean of IFN titers assayed with $60 \mu \mathrm{g} /$ $\mathrm{ml}$ of cimetidine was significantly higher $(p<0.05)$ than that without cimetidine (Table 1).

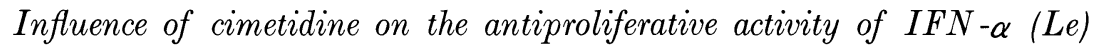

Table 3 shows the combination cell growth inhibitory effects of IFN- $\alpha$ (Le) and cimetidine on Daudi cells. IFN alone suppressed the cell growth of this cell line in about $26 \%$ at $2 \mathrm{IU} / \mathrm{ml}$, and $40 \%$ at $5 \mathrm{IU} / \mathrm{ml}$. On the other hand, the growth of Daudi cells was inhibited approximately $11 \%$ by $0.6 \mu \mathrm{g} / \mathrm{ml}, 12 \%$ by 6 $\mu \mathrm{g} / \mathrm{ml}$, and $16 \%$ by $60 \mu \mathrm{g} / \mathrm{ml}$ of cimetidine alone. As both IFN and cimetidine showed the cell growth inhibitory effects, the combination effects of these two agents were analyzed as mentioned above. As indicated in Table 3 the observed

TABLE 3. Influence of cimetidine on the antiproliferative activity of $H u I F N-\alpha(L e)$ on Daudi cells*

\begin{tabular}{ccccc}
\hline $\begin{array}{c}\text { HuIFN- } \alpha(\mathrm{Le}) \\
\text { concentration } \\
(\mathrm{IU} / \mathrm{ml})\end{array}$ & \multicolumn{4}{c}{$\begin{array}{c}\text { Growth inhibition rates }(\%) \dagger \\
\text { Cimetidine concentration }(\mu \mathrm{g} / \mathrm{ml})\end{array}$} \\
\cline { 2 - 5 } & 0 & 0.6 & 6 & 60 \\
\hline 0 & - & $11.3 \pm 6.6$ & $12.2 \pm 8.5$ & $16.2 \pm 12.5$ \\
2 & $25.6 \pm 3.9$ & $36.7 \pm 0.2$ & $41.7 \pm 6.4$ & $46.0 \pm 2.2$ \\
& - & 34.0 & 34.7 & 37.7 \\
$($ expected $\ddagger)$ & - & $+0.77[\mathrm{~A}]$ & $+1.43[\mathrm{~A}]$ & $+1.72[\mathrm{~A}]$ \\
5 & & $49.7 \pm 3.2$ & $52.3 \pm 8.8$ & $60.3 \pm 6.4$ \\
$($ (expected) & - & 46.3 & 46.9 & 49.3 \\
$(\mathrm{CI} / \mathrm{SE})$ & - & $+1.25[\mathrm{~A}]$ & $+1.15[\mathrm{~A}]$ & $+2.55[\mathrm{~S}]$ \\
\hline
\end{tabular}

* $6 \times 10^{5}$ cells were cultured with interferon and/or cimetidine. Cell growth inhibition rates were evaluated on Day-3. The mean of the control cell growth (without IFN or cimetidine) was $853.7 \%$.

$\dagger$ Mean \pm s.D. of 6 experiments is given.

$\ddagger$ The expected value was calculated in each combination of interferon and cimetidine following the method of Spector et al. (1982).

$\S \mathrm{CI} / \mathrm{SE}$ was calculated in each combination to evaluate the mode of combination effect. [A], additive; [S], synergistic. 
TABLE 4. Influence of cimetidine on the antiproliferative activity of $H u I F N-\alpha$ (Le) on $G-361$ cells*

\begin{tabular}{|c|c|c|c|}
\hline \multirow{2}{*}{$\begin{array}{l}\text { HuIFN- } \alpha \text { (Le) } \\
\text { concentration } \\
(\mathrm{IU} / \mathrm{ml})\end{array}$} & \multicolumn{3}{|c|}{$\begin{array}{c}\text { Growth inhibition rates }(\%) \dagger \\
\text { Cimetidine concentration }(\mu \mathrm{g} / \mathrm{ml})\end{array}$} \\
\hline & 0 & 3 & 30 \\
\hline \multicolumn{4}{|l|}{ Experiment $1 \quad(n=3)$} \\
\hline 0 & - & $6.9 \pm 6.9$ & $10.8 \pm 10.2$ \\
\hline $\begin{array}{l}100 \\
\quad(\text { expected } \ddagger) \\
(\mathrm{CI} / \mathrm{SE} \S)\end{array}$ & $\begin{array}{c}27.2 \pm 4.0 \\
- \\
-\end{array}$ & $\begin{array}{c}49.2 \pm 3.3 \\
32.2 \\
+4.00[\mathrm{~S}]\end{array}$ & $\begin{array}{l}69.1 \pm 5.7 \\
\quad 35.5 \\
+4.82[\mathrm{~S}]\end{array}$ \\
\hline \multicolumn{4}{|l|}{ Experiment $2(n=4)$} \\
\hline 0 & - & $-3.2 \pm 5.4$ & $15.3 \pm 3.4$ \\
\hline $\begin{array}{l}100 \\
\quad(\text { expected }) \\
\quad(\mathrm{CI} / \mathrm{SE})\end{array}$ & $\begin{array}{c}16.6 \pm 5.0 \\
- \\
-\end{array}$ & $\begin{array}{c}26.5 \pm 7.2 \\
14.0 \\
+2.20[\mathrm{~S}]\end{array}$ & $\begin{array}{l}38.0 \pm 4.0 \\
\quad 29.4 \\
+2.24[\mathrm{~S}]\end{array}$ \\
\hline \multicolumn{4}{|c|}{ Experiment $3(n=4)$} \\
\hline 0 & - & $1.0 \pm 5.4$ & $8.8 \pm 7.8$ \\
\hline $\begin{array}{l}500 \\
\quad \text { expected) } \\
(\mathrm{CI} / \mathrm{SE})\end{array}$ & $\begin{array}{c}53.3 \pm 5.6 \\
- \\
-\end{array}$ & $\begin{array}{c}57.0 \pm 3.6 \\
53.3 \\
+0.91[\mathrm{~A}]\end{array}$ & $\begin{array}{l}65.4 \pm 3.6 \\
\quad 57.4 \\
+2.31[\mathrm{~S}]\end{array}$ \\
\hline
\end{tabular}

* $2 \times 10^{4}$ cells were cultured with interferon and/or cimetidine. Viable cells were counted and the cell growth inhibition rates were evaluated. The means of the control cell growth were $373.5 \%$ (exp. 1), 613.2\% (exp. 2) and $809.7 \%$ (exp. 3).

$\dagger$ Mean \pm s.D. is given.

$\ddagger \& \S$ The expected value and CI/SE in each combination were calculated as indicated in the legend of TABLE 3. [A], additive; [S], synergistic.

cell growth inhibition rate was higher than the expected value in each combination of IFN- $\alpha$ (Le) and cimetidine. However, only in the combination of $5 \mathrm{IU} /$ $\mathrm{ml}$ of IFN and $60 \mu \mathrm{g} / \mathrm{ml}$ of cimetidine, the combination effect was revealed to be synergistic statistically, and to be additive in the others.

The results of three experiments on the G-361 cells were shown in Table 4. Against this cell line, $3 \mu \mathrm{g} / \mathrm{ml}$ of cimetidine did not show remarkable cell growth inhibitory effect, whereas $30 \mu \mathrm{g} / \mathrm{ml}$ of cimetidine inhibited the growth in approximately $12 \%$ in the mean. IFN- $\alpha$ (Le) suppressed the growth of this cell line in about $20 \%$ at $100 \mathrm{IU} / \mathrm{ml}$, and $53 \%$ at $5,000 \mathrm{IU} / \mathrm{ml}$. When both agents were combined, the observed cell growth inhibition rate in each combination was much higher than the expected value. Except one experiment with $5,000 \mathrm{IU} / \mathrm{ml}$ of IFN- $\alpha$ (Le) and $3 \mu \mathrm{g} / \mathrm{ml}$ cimetidine where it was found to be additive, the combination effect of each concetration of IFN and cimetidine was revealed to be synergistic, statistically (Table 4). Mock interferon did not show any cell growth inhibitory effect at all against these two cell lines (data not shown). 
TABle 5. Augmentation of natural killer cell activity of PBL pretreated with cimetidine by $\mathrm{HuIFN}-\alpha(L e)^{*}$

\begin{tabular}{|c|c|c|c|c|}
\hline \multirow{2}{*}{ HuIFN- $\alpha$ (Le) } & \multicolumn{4}{|c|}{$\% \mathrm{NK}$ cell activity of $\mathrm{PBL}$ pretreated with cimetidine } \\
\hline & no cimetidine & $0.3 \mu \mathrm{g} / \mathrm{ml}$ & $3 \mu \mathrm{g} / \mathrm{ml}$ & $30 \mu \mathrm{g} / \mathrm{ml}$ \\
\hline I. no interferon & $21.7 \pm 2.1$ & $19.4 \pm 3.2 \ddagger$ & $18.0 \pm 2.1+\ddagger$ & $20.1 \pm 2.7^{\mathrm{ns}}$ \\
\hline 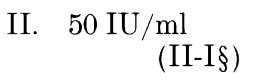 & $\begin{array}{l}23.3 \pm 5.9 \\
\quad(1.7)\end{array}$ & $\begin{array}{c}25.7 \pm 5.2 \\
(6.3)\end{array}$ & $\begin{array}{c}25.5 \pm 3.7 \\
\left(7.5^{* *}\right)\end{array}$ & $\begin{array}{c}26.5 \pm 4.9 \\
\left(6.3^{*}\right)\end{array}$ \\
\hline $\begin{array}{l}\text { III. } 500 \mathrm{IU} / \mathrm{ml} \\
(\mathrm{III}-\mathrm{I} \S)\end{array}$ & $\begin{array}{l}32.0 \pm 3.0 \\
(10.3)\end{array}$ & $\begin{array}{c}33.6 \pm 2.7 \\
\left(14.2^{*}\right)\end{array}$ & $\begin{array}{c}30.9 \pm 1.5 \\
\left(12.9^{*}\right)\end{array}$ & $\begin{array}{l}34.0 \pm 3.6 \\
\left(13.9^{*}\right)\end{array}$ \\
\hline $\begin{array}{r}\text { IV. } 5000 \mathrm{IU} / \mathrm{ml} \\
(\mathrm{IV}-\mathrm{I} \S)\end{array}$ & $\begin{array}{l}35.6 \pm 3.9 \\
(14.0)\end{array}$ & $\begin{array}{l}37.2 \pm 3.0 \\
\left(17.8^{*}\right)\end{array}$ & $\begin{array}{l}36.8+4.0 \\
\left(18.8^{* *}\right)\end{array}$ & $\begin{array}{l}39.7 \pm 3.4^{*} \\
\left(19.6^{* *}\right)\end{array}$ \\
\hline
\end{tabular}

* After pretreated with or without cimetidine for $16 \mathrm{hr}$, PBL were treated with or without HuIFN- $\alpha$ (Le) for $2 \mathrm{hr}$. The assay of the NK cell activity was done at E/T ratio of 50 by $4 \mathrm{hr}{ }^{51} \mathrm{Cr}$ releasing cytotoxicity test against K-562 target cells.

$\dagger$ Mean \pm s.D. $(\%)$ of twelve experiments.

$\S \% \mathrm{NK}$ above no interferon treatment by each concentration of interferon was calculated by subtracting the $\% \mathrm{NK}$ without interferon from that with interferon.

$\ddagger p<0.05 ;$;,$p<0.01$ when compared with the value without cimetidine or interferon.

*, $P<0.05$; $^{* *} p<0.01$ when compared with the value without cimetidine.

\section{Influence of cimetidine on the NK augmentation activity of IFN- $\alpha$ (Le)}

Table 5 summarizes the NK cell activity of PBL after a $16 \mathrm{hr}$ pretreatment with or without three concentrations of cimetidine followed by a $2 \mathrm{hr}$ incubation with IFN- $\alpha$ (Le). Compared to untreated controls, the NK cell activity was suppressed by the cimetidine treatment (for $16 \mathrm{hr}$ ). The mean NK cell activity found at $0.3 \mu \mathrm{g} / \mathrm{ml}(p<0.05)$ and at $3 \mu \mathrm{g} / \mathrm{ml}(p<0.01)$ was significanyly lower than the control, respectively. The viability of $\mathrm{PBL}$ after the $16 \mathrm{hr}$ treatment with each concentration of cimetidine was more than $98 \%$ and not impared when tested by the dye exclusion technique using Trypan Blue solution. By the 2 hour treatment with IFN, the NK cell activity was augmented dosedependently in each experiment group. The magnitude of augmentation, evaluated by the NK cell activity above no IFN treatment indicated in parenthesis in Table 5 was found to be statistically higher in each cimetidine pretreated group, except one, than that without cimetidine pretreatment.

In Fig. 1, the NK cell activity of PBL treated with various concentrations of IFN- $\alpha$ (Le) and/or cimetidine for $16 \mathrm{hr}$. The mean NK cell activities of PBL treated with cimetidine but without IFN were slightly lower than that without cimetidine nor IFN, respectively. On the other hand, the NK cell activity was dosedependently augmented by IFN at each concentration of cimetidine selected, and that of IFN/cimetidine combination group was more pronouncedly enhanced compared to IFN alone (Fig. 1). At 3,000 IU $/ \mathrm{ml}$ of IFN- $\alpha$ (Le), the means \pm s.D. 


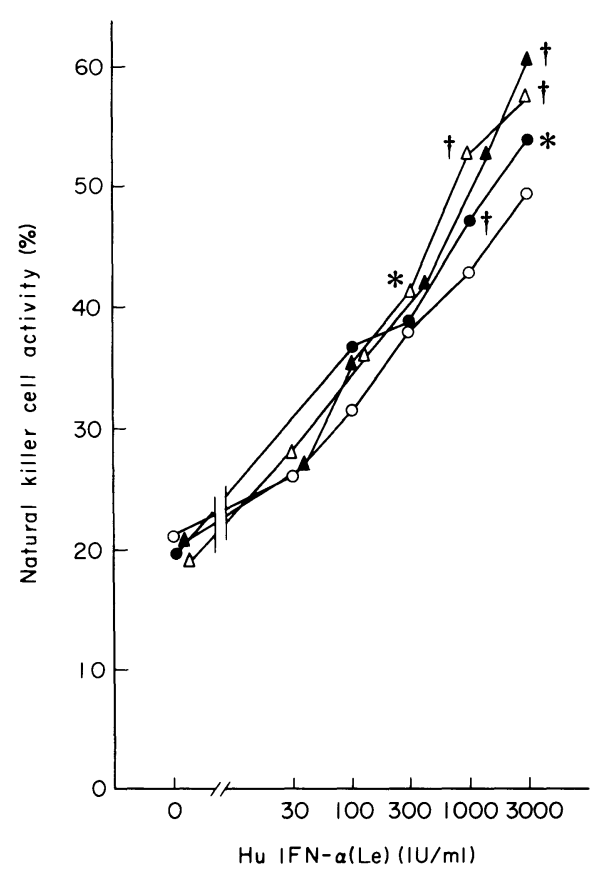

Fig. 1. Augmentation of NK cell activity of PBL treated with $0(\bigcirc), 0.3(\mathbf{\bullet}), 3$ $(\triangle)$ and $30(\Delta) \mu \mathrm{g} / \mathrm{ml}$ of cimetidine and IFN- $\alpha$ (Le) for $16 \mathrm{hr}$.

The assay of NK cell activity was done at an E/T ratio of 50 and by a $4 \mathrm{hr}$ cytotoxicity test at $37^{\circ} \mathrm{C}$. The $\mathrm{NK}$ cell activities indicated in the figure are the mean values of eight experiments.

${ }^{*} p<0.05 ; \dagger p<0.01$ when compared with that without cimetidine treatment.

of the NK cell activities with cimetidine were $54.3 \pm 4.4 \%$ (at $0.3 \mu \mathrm{g} / \mathrm{ml}$ ), $57.9 \pm$ $6.6 \%($ at $3 \mu \mathrm{g} / \mathrm{ml}$ ) and $60.9 \pm 4.0 \%$ (at $30 \mu \mathrm{g} / \mathrm{ml}$ ), which were significantly $(p<$ 0.05 at $0.3 \mu \mathrm{g} / \mathrm{ml} ; p<0.01$ at 3 and $30 \mu \mathrm{g} / \mathrm{ml}$ ) higher than the activity without cimetidine $(49.6 \pm 2.1 \%)$, respectively.

The cimetidine effect on the NK cell activity was also tested agaist two other cell lines, G-361 and PLC/PRF/5 cells, in 5 experiments indicated in Fig. 2. In these experiments, PBL were pretreated with or without $3 \mu \mathrm{g} / \mathrm{ml}$ of cimetidine followed by the treatment with $5,000 \mathrm{IU} / \mathrm{ml}$ of IFN- $\alpha$ (Le). The NK cell activity of $\mathrm{PBL}$ pretreated with cimetidine alone was also slightly suppressed against those cell lines. The means \pm s.D. of the augmentation of NK cell activity above no IFN treatment in PBL pretreated with cimetidine against K-562, G-361 and $\mathrm{PLC} / \mathrm{PRF} / 5$ target cells were $27.5 \pm 3.1 \%(p<0.001), 23.2 \pm 2.4 \%(p<0.01)$ and $32.2 \pm 2.6 \% \quad(p<0.05)$, and significantly higher than the activity without cimetidine pretreatment, $(12.7 \pm 1.7 \%, 17.0 \pm 2.8 \%$ and $26.8 \pm 4.3 \%)$ respectively.

The IFN activity (the antiviral activity) of the supernatant from the $16 \mathrm{hr}$ PBL culture with each concentration of cimetidine in several experiments was tested by using CPE inhibition assay on GM cells challenged by VSV. No (less 


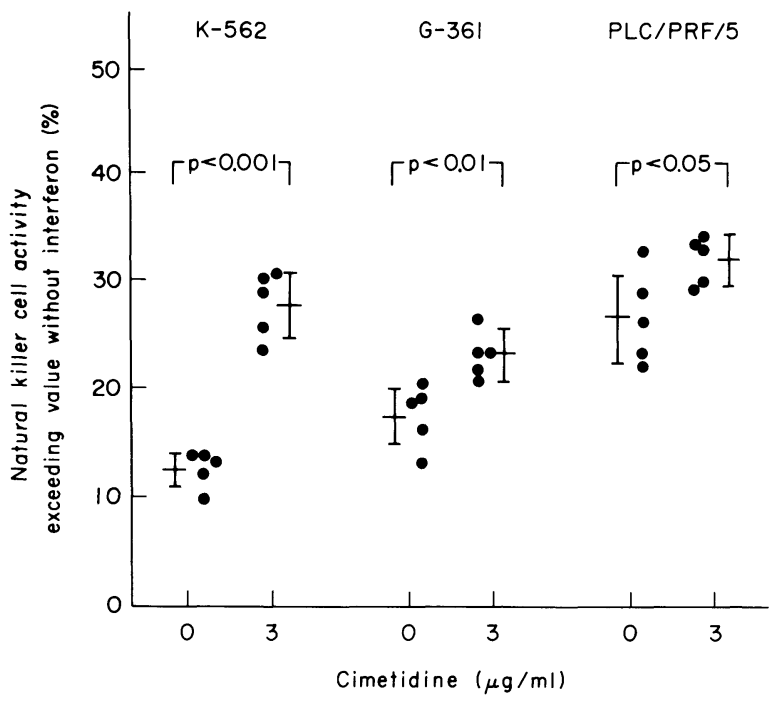

Fig. 2. Augmentation of NK cell activity of PBL pretreated with cimetidine by IFN- $\alpha$ (Le). After pretreated with or without $3 \mu \mathrm{g} / \mathrm{ml}$ of cimetidine for 16 $\mathrm{hr}$, normal PBL was terated with or without $5,000 \mathrm{IU} / \mathrm{ml}$ of IFN for $5 \mathrm{hr}$. The assay was done at an $\mathrm{E} / \mathrm{T}$ ratio of 50 and by a $16 \mathrm{hr}$ cytotoxicity test. NK cell activity above no IFN was estimated by the difference in NK cell activity between "with" and "without" IFN treatment.

Fig. 3. Interferon production in PBL cultures treated with cimetidine for $16 \mathrm{hr}$. After the treatment with $0,0.3,3$ and $30 \mu \mathrm{g} / \mathrm{ml}$ of cimetidine for $16 \mathrm{hr}, 6 \times 10^{6}$ of $\mathrm{PBL}$ were primed with 100 $\mathrm{IU} / \mathrm{ml}$ of IFN- $\alpha$ (Le) for $2 \mathrm{hr}, 150 \mathrm{HAU} / \mathrm{ml}$ of Sendai virus was added, and the cells were cultured for $24 \mathrm{hr}$ at $37^{\circ} \mathrm{C}$. After UV irradition, the IFN yields in the culture supernatants were assayed by the plaque reduction method.

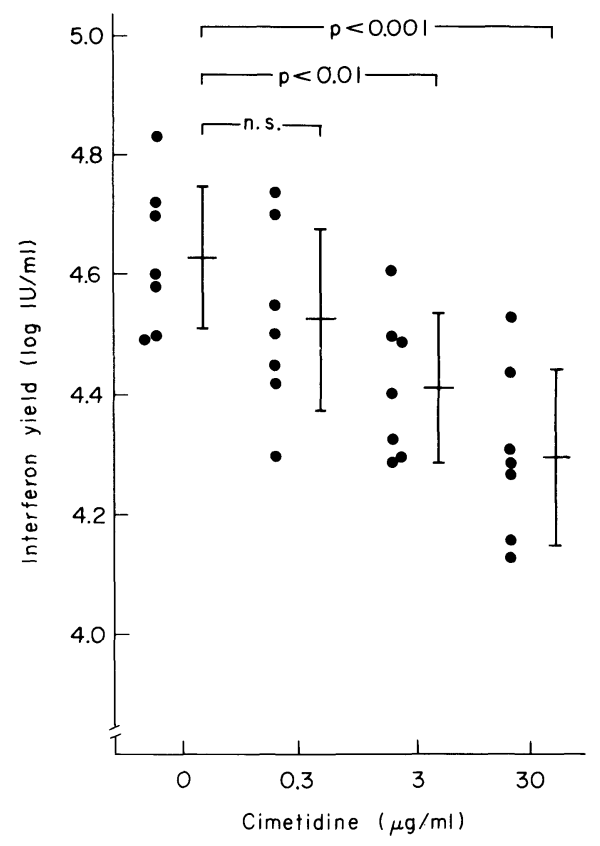


than $4 \mathrm{IU} / \mathrm{ml}$ ) interferon activity was detectable at all.

\section{Influence of cimetidine on the interferon production in $P B L$}

The effect of cimetidine was also tested on the IFN production in normal PBL cultures induced by Sendai Virus. As shown in Fig. 3 , the IFN yield induced by Sendai virus in PBL treated with selected concentrations of cimetidine was suppressed dosedependently when compared to that without cimetidine treatment. The IFN production in PBL treated with $3 \mu \mathrm{g} / \mathrm{ml}(p<$ $0.01)$ and $30 \mu \mathrm{g} / \mathrm{ml}(p<0.001)$ of cimetidine were significantly lower than that without cimetidine.

\section{Discussion}

Our results indicated that the presence of cimetidine can dosedependently potentiate the antiviral state in U cells induced by IFN- $\alpha$ (Le) (Tables 1 and 2), and that IFN- $\alpha$ (Le) and cimetidine have additive or synergistic combined inhibitory effects on the growth of two human malignant cell lines (Tables 3 and 4). Also, it was suggested that cimetidine may potentiate the NK augmenting activity of IFN- $\alpha$ (Le) (Table 5, Fig. 1 and 2), whereas cimetidine alone seems to suppress the NK cell activity of PBL in accordance with the reduction of IFN production in PBL treated with cimetidine (Fig. 3).

Cimetidine is one of the most widely used histamine $\mathrm{H}-2$ receptor antagonists, for instance, in the treatments of peptic ulcers and acute gastrointestinal bleedings (Freston 1982). Recently, this drug was reported to have possible antitumoral effects in mice as well as in humans as mentioned above. Lately, Borgeström et al. (1982) and Hill et al. (1983) have reported that partial and complete responces were obtained in some of the patients with malignant melanomas by an IFN- $\alpha$ (Le) treatment combined with cimetidine administration, whereas IFN- $\alpha$ (Le) alone did not seem to benefit such patients. The mechanisms of the antitumoral action of cimetidine may be generally considered to be due to its immunomoduratory action including the reduction of the suppressor cell activity (Ogden et al. and Hill 1980; Meretey et al. 1981; Siegel es al. 1982). However, other reports, suggesting that cimetidine has suppressed the growth of human colorectal tumors xenografted on the immunodeprived mice (Tutton and Steel 1979; Tutton and Barkla 1983) seem to imply the possibility that cimetidine may also have a direct inhibitory effect on the growth of these target cells.

Our results have suggested that the cimetidine can directly inhibit the growth of at least two human malignant cell lines in vitro. When a higher concentration $(600 \mu \mathrm{g} / \mathrm{ml})$ of cimetidine was tried, Daudi cells were completely killed after a few days (data not shown). On the other hand, Gifford et al. (1981a) reported that cimetidine did not have any cytotoxic effect on a mouse cell line used in their laboratory. However, the concentration of cimetidine used in their experiments 
was not mentioned.

Regarding to the concentration levels of cimetidine used in this study, the lower doses $(0.6,3$, and $6 \mu \mathrm{g} / \mathrm{ml})$ are known to be pharmacological levels and the higher ones ( 30 and $60 \mu \mathrm{g} / \mathrm{ml}$ ) may be considered to be over doses in vivo (Sawyer et al. 1981). As shown in our results, the growth of Daudi cells was inhibited in the lower doses as well as in higher one, and as for G-361 cells, it was suppressed in the higher dose but not in the lower one. Thus, cimetidine is considered to have a direct cell growth inhibitory effect at least on some malignant cells even at pharmacological doses, whereas the sensitivity of the cells to this cimetidine effect seems to differ from cell line to cell line.

Although the precise mechanisms of IFN actions are not established, several reports (Kerr and Brown 1978; Zilberstein et al. 1978)have indicated that several intracellular proteins induced by the IFN molecules bound to the receptors on the cell membrane may inhibit the viral replications. Therefore, it is now considered that the antiviral activity of interferons may be probably generated by these proteins inside the target cells. Moreover, in a recent study (Creasey et al. 1983), the level of $\left(2^{\prime}-5^{\prime}\right)$ oligoadenylate synthetase, one of these intracellular proteins, showed an inversed correlation to the relative number of melanoma cells in $\mathrm{S}$ phase. Hence, it is possible that the antiproliferative activity of IFN may be also generated by the same kind of intracellular proteins induced by IFN molecules.

Our results indicated that cimetidine seems to potentiate both of the antiviral and the antiproliferative activities of IFN- $\alpha$ (Le) in an additive or synergistic manner. In other experiments, where the target cells were pretreated with cimetidine prior to the IFN treatment, we also observed that the cimetidine effects to potentiate both IFN activities retained (but less pronounced) for 2 to 5 days after the drug had been removed from the culture medium (data not shown).

It is possible that both of the antiviral and the antiproliferative activites of IFN might be generated by the same intracellular pathway, at least partially, as mentioned above. If so, cimetidine might play a role in accerating or increasing quantitatively the development of such intracellular proteins inside the target cells.

As for the effects of cimetidine on the NK cell activity, recent studies have indicated that cimetidine may suppress the NK cell activity of PBL against $\mathrm{K}$ 562 cells (Láng et al. 1981 ; Reiz-Argüelles et al 1982 ; Nair et al. 1983.) However, with respect to the concentration levels of cimetidine, there seem to be considerable differences in these reports. Especially at the pharmacological doses of cimetidine, Ruiz-Argüelles et al. (1982) reported a clear suppression of the NK cell activity, but Láng et al. (1981) did not observe any prominent suppression, and Nair et al. (1983) only tried the over doses of cimetidine.

In regards to our results, we found that the NK cell activity was slightly suppressed at considerable pharmacological concentrations $(0.3$ and $3 \mu \mathrm{g} / \mathrm{ml})$, when PBL was preincubated with cimetidine for $16 \mathrm{hr}$ (Table 5). However, the 
degree of suppression was not so prominent as Ruiz-Argüelles et al. (1982) reported.

It is known that endogenous as well as exogenous IFN is of importance for the NK cell activity. Trinchieri et al. (1977) indicated that lymphocytes incubated with tumor cell lines for a few hours in vitro released IFN into the culture medium. It has also been observed that anti-IFN antiserum added directly to the NK assay system reduced the NK cell activity remarkably (Dr. Kurt Berg, personal communication). Our results of IFN production in PBL pretreated with cimetidine indicated a remarkable dosedependent suppression of IFN production by these cells (Fig. 3). Based upon these experimental results, we anticipate that the suppressive effect of cimetidine on the NK cell activity may be due to a reduction of the endogenous IFN production in the effector PBL treated with cimetidine.

Besides the antiproliferative activity, one of the most widely recognized non-antiviral actions of IFN is to augment the NK cell activity by acting on the maturation process of NK cells from pre-NK cells (Saksela et al. 1979). We found that either the pretreatment with cimetidine or the presence of this drug enhanced the activity of IFN- $\alpha$ (Le) on the NK cell system. Cimetidine is known to have various immunomodulatory effects including the reduction of the suppressor cell activities as mentioned above. Based upon the fact that the NK cell system is also controlled, at least partially, by suppressor T cells, (Herberman 1982), we suppose that the enhanced NK augmenting activity of IFN- $\alpha$ (Le) induced by cimetidine is probably due to the cimetidine related reduction of the suppressor cell activity on this immunosurveillance system. Another possibility may be that the immunomodulatory effects of IFN might involve the same cellular mechanisms (Stewart II 1979), and that cimetidine might have the same effect on the NK augmenting activity as on the antiviral and antiproliferative activities of IFN- $\alpha$ (Le).

Our in vitro observations seem to sustain the possibility that the combination of IFN and cimetidine, tried preliminarily by Borgeström et al. (1982) and Hill et al. (1983) may be beneficial in the cancer treatments. Further studies including in vivo trials against various malignant tumors are needed to elucidate this possibility.

\section{Acknowledgments}

Thanks are due to Dr. K. Cantell for the kind supply of U Amnion Cells, Vesicular Stomatitis Virus and Sendai Virus.

\section{References}

1) Armitage, J.O. \& Sindner, R.D. (1979) Antitumor effect of cimetidine. Lancet, 1, 882-883.

2) Berg, K., Osther, K. \& Heron, I. (1980) Production, purification, and properties of 
human interferons. In: Interferon and Interferon Inducers, edited by D.A. Stringfellow, Marcel Dekker, Inc., New York and Basel, pp. 21-55.

3) Borgeström, S., von Eyben, F.E., Flodgren, P., Axelsson, R. \& Sjögren, H.O. (1982) Human leucocyte interferon and cimetidine for metastic melanoma. New Engl. J. Med., 307, 1080-1081.

4) Cantell, K., Hirvonen, S., Kauppinen, H.L. \& Myllylä, G. (1981) Production of interferon in human leucocytes from normal donors with use of Sendai virus. Methods in Enzymol., 78, 29-38.

5) Creasey, A.A., Epstein, D.A., Marsh, Y.V., Khan, S. \& Merigan, T.C. (1983) Growth regulation of melanoma cells by interferon and $\left(2^{\prime}-5^{\prime}\right)$ oligoadenylate synthetase. Mol. cell. Biol., 3, 780-786.

6) Djeu, J.Y.,, Heinbaugh, J.A., Holden, H.T. \& Herberman, R.B. (1979) Augmentation of mouse natural killer cell activity by interferon and interferon inducers. $J$. Immunol., 122, 175-181.

7) Freston, J.W. (1982) Cimetidine. I. Developments, pharmacology and efficacy. Ann. intern. Med., 97, 573-580.

8) Gifford, R.R.M., Ferguson, R.M. \& Voss, B.V. (1981a) Cimetidine reduction of tumor formation in mice. Lancet, 1, 638-640.

9) Gifford, R.R.M., Voss, B.V. \& Ferguson, R.M. (1981b) Cimetidine protection against lethal tumor challenge in mice. Surgery, 90, 344-351.

10) Herberman, R.B. (1982) Natural killer cells. Hosp. Practice, 17, 93-103.

11) Hill, N.O., Pardue A., Hill, R.W., Aleman, C., Hilario, R., Hill, J.M. \& Osther, K. (1983) Interferon and cimetidine for malignant melanoma. New Engl. J. Med., 308, 206.

12) Kerr, I.M. \& Brown, R.E. (1978) pppA2' $5^{\prime}$ A2 $^{\prime}$ p5 $5^{\prime}$ A, an inhibitor of protein synthesis synthesized with an enzyme fraction from interferon treated cells. Proc. nat. Acad. Sci. USA, 75, 4734-4738.

13) Láng, I, Gergely, R. \& Petrani, G.Y. (1981) Effect of histamine-receptor blocking on human spontaneous lymphocyte mediated cytotoxicity. Scand. J. Immunol., 14, 573-576.

14) Langford, M.P., Weigt, D.A., Stanton, G.J. \& Baron, S. (1981) Virus plaque reduction assay for interferon; microplaque and regular macroplaque reduction assays. Methods in Enzymol., 78, 339-346.

15) Meretey, K., Room, G. \& Maini, R.N. (1981) Effects of histamine on the mitogenic responces of human lymphocytes and modification by cimetidine and levamisol. Agents and Actions, 11, 84-88.

16) Nair, M.P.N. \& Schwartz, S.A. (1983) Effect of histamine and antagonists on natural and antibody-dependent cellular cytotoxicity of human lymphocytes in vitro. Cell. Immunol., 81, 45-60.

17) Ogden, B.E. \& Hill, H.R. (1980) Histamine regulates lymphocyte mitogenic responses through activation of specific $\mathrm{H} 1$ and $\mathrm{H} 2$ histamin receptors. Immunology, 41, 107-114.

18) Osband, M.E., Lavin, P., Brown, A. \& McCaffrey, R. (1981) Successful tumor immunotherapy with cimetidine in mice. Lancet, 1, 636-638.

19) Ruiz-Argüelles, A., Serogy, K.B. \& Ritts, R.E. (1982) In vitro effect of cimetidine on human cellmediated cytotoxicity. Cell. Immunol., 69, 1-12.

20) Saksela, E., Timonen, T. \& Cantell, K. (1979) Human natural killer cell activity is augmented by interferon via recruitment of 'pre-NK' cells. Scand. J. Immunol., 10, $257-266$.

21) Sawyer, D., Conner, C.S. \& Scalley, R. (1981) Cimetidine; adverse reactions and acute toxicity. Amer. J. Hosp. Pharm., 38, 187-197.

22) Siegel, J.N., Schwartz, A., Askenase, P.W. \& Gershon, R.K. (1982) T-cell suppression and contrasuppression induced by histamine $\mathrm{H} 2$ and $\mathrm{H} 1$ receptor agonists, respective- 
ly. Proc. nat. Acad. Sci. USA, 79, 5052-5056.

23) Spector, A.A., Tyndall, M. \& Kelley, E. (1982) Effects of acyclovir combined with other antiviral agents on human cytomegalovirus. Amer. J. Med., 73, IA 36-39.

24) Stewart, W.E., II (1979) The Interferon System, Springer-Verlag, Wien, New York, pp. 223-256.

25) Tutton, P.J.M. \& Steel, G.G. (1979) Influence of biogenic amines on the growth of xenografted human colorectal carcinomas. Brit. J. Cancer, 40, 734-749.

26) Tutton, P.J.M. \& Barkla, D.H. (1983) Comparison of the tumor inhibiting effects of three histamine $\mathrm{H} 2$ receptor antagonists. Anticancer Res., 3, 7-10.

27) Trinchieri, G., Santoli, D. \& Knowles, B.B. (1977) Tumor cell lines induced interferon in human lymphocytes. Nature, 270, 611-613.

28) Yamauchi, K., Fujimoto, S. \& Tada, T. (1979) Differential activation of cytotoxic and suppressor $\mathrm{T}$ cells against syngenic tumors in the mouse. $J$. Immunol., 123, 1653-1658.

29) Zilberstein, A., Kimchi, A., Schmidt, A. \& Revel, M. (1978) Isolation of two inter feron-induced translational inhibitors; A protein kinese and an oligo-isoadenylate synthetase. Proc. nat. Acad. Sci. USA, 75, 4734-4738. 